\title{
Nursing Students' Perception of the Use of Google Classroom in TOEFL Preparation
}

\author{
Nyanyu Yayu Suryani ${ }^{1}$, Syamsul Rizal ${ }^{2}$, Abdul Aziz Rifa'at ${ }^{3}$ \\ 1,3 Sekolah Tinggi Ilmu Kesehatan Siti Khadijah Palembang, Indonesia \\ 2Institut Agama Islam Negeri (IAIN) Bengkulu, Indonesia \\ Corresponding Author: nyayu.ys@stikes-sitikhadijah.ac.id
}

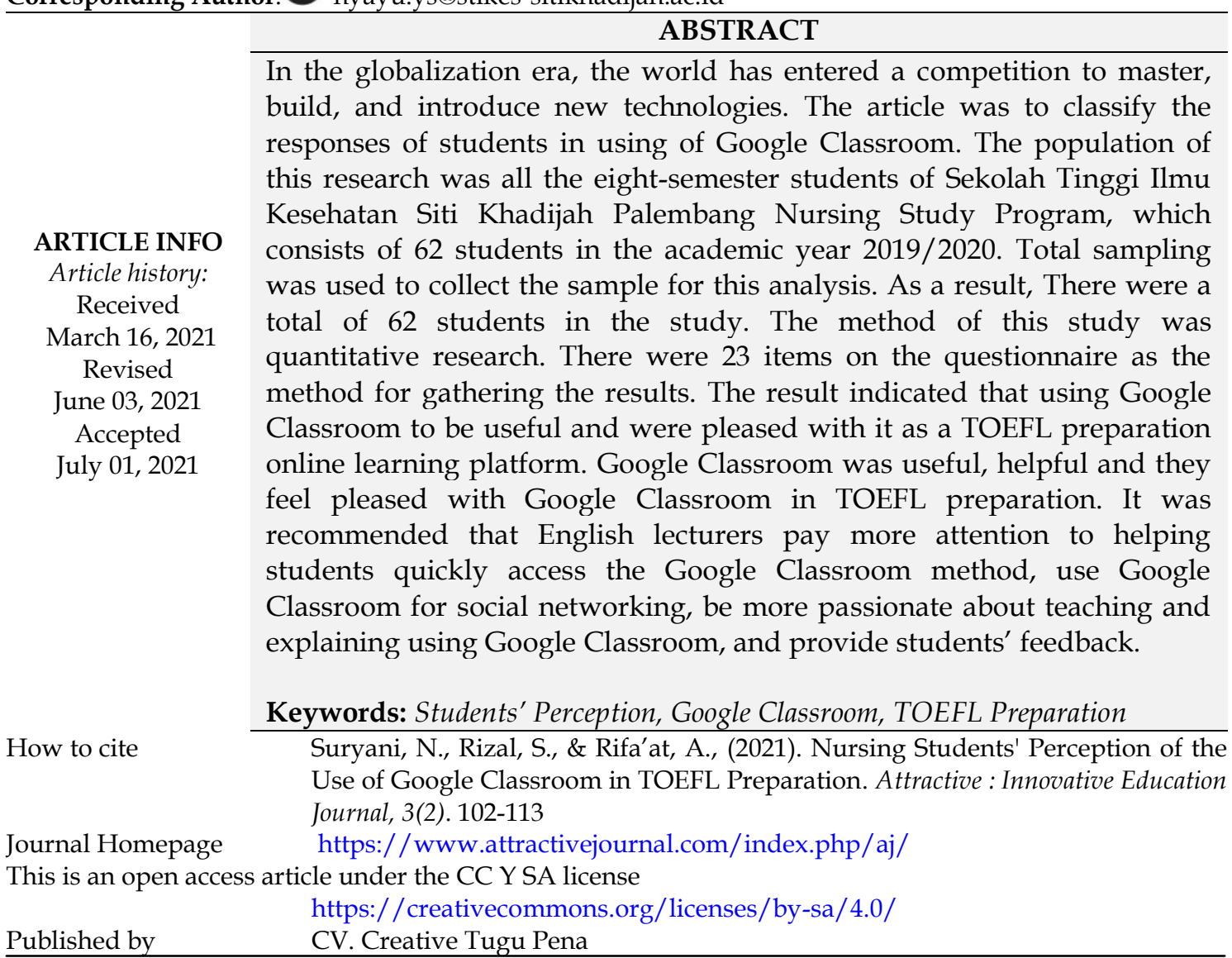

\section{INTRODUCTION}

Nowadays, the incorporation of technology or ICT would encourage students to monitor their training and engage in classes even more. The incorporation of technology in the classroom is highly emphasized through creative teaching methods that assist students in achieving their desired learning results (Hwang et al., 2015). TOEFL is a test that assesses a student's comprehension and application of the English language. The TOEFL (Test of English as a Foreign Language), pronounced "toe-full," is a test of English as a foreign language, or even simply "toffle" assesses an individual's possible performance in using and interpreting regular American English at the college level (Sari, et al., 2021; Ockey, et al., 2015; Becker, 2016). This is expected for non-native applicants at several American and English-speaking colleges and universities (Al Rawashdeh, 2011).

Effectively preparing, committed and genuine commitment from both the instructor and the student would require good TOEFL test preparation. TOEFL is a

\section{Attractive : Innovative Education Journal}

Vol. 3, No. 2, July 2021

ISSN : 2685-6085 
complex test, and the only way to do well in this test is to prepare correctly (Inoue, C., \& Lam, D. M. 2021). A thorough comprehension of the topic and honestly executed planning for the TOEFL exam will help you achieve a high TOEFL score.

The online community conversation is regarded by students as an online learning experience that will help them encourage and enhance their language learning (Kabilan et al., 2010). In many ways, online learning can benefit students, particularly for those who suffer from social anxiety; it can be a relief that without feeling awkward around other students, they can easily inquire and comment. On learning, technology impacts students. It will inspire profound improvements. Technology implementation is required, especially to enhance the output of students and easy in using learning (Suhono, et al., 2020; Wawan, et al., 2018). Through the introduction of technology, it is expected that the success of students will be more successful and efficient. Therefore, their productivity would be maximal. Sadly, there are also challenges to the introduction of technologies. The restrictions that often occur are linked to the efficacy of technology use.

Google Classroom can be used to improve classroom efficiency as a blended learning method. The lack of Google classroom study, especially in the context of developing countries, has given rise to the needy to further investigate the effectiveness of the instrument (Hemrungrote, et al., 2017; Gupta, A., \& Pathania, P. 2021) One of the main impediments for teachers to manage in a blended teaching environment is the use of technology in an acceptable manner; thus this study will focus on assessing the performance of Google Classroom in EFL classes. Students are expected to have a desktop, computer, smartphone, and gadget that supports Google classroom functionality due to the Google Classroom applications' defects.

Teachers need to worry about using the Google classroom as a means of instruction since not every student has access to a laptop or an Android smartphone. Students with a smartphone are not supposed to use their smartphone to play games and social media, but can use it for learning processes as well. Since Google Classroom is now an online learning tool that is app-based and web-friendly, several scholars have tried to recognize the opportunities and challenges of Google Classroom in terms of teaching and learning diverse subjects from various disciplines, including education, social studies, business studies, and so on However, there has not been much study done about how to teach and learn English using Google Classroom. Because of this, as a research void, the researcher attempted, through this article, to figure out the perception of tertiary-level learners against the perception of using a Google classroom in terms of learning English. The question may emerge as, why the researcher wants to find out learners' interpretation. Learning English is less about learning the skills of reading, writing, listening in TOEFL preparation skills.

\section{Students' perception}

The perceptions of students in university education regarding e-learning can be affected by particular variables. There are at least three characteristics in addition to the variables of age and gender: prior computing knowledge, technology acceptance, and the individual way to learn (Keller \& Cernerud, 2002). Understanding the perception of students of their learning becomes a major variable in examining the contribution of higher education in the process of transfer from the university to the decisions a student makes in various settings, taking into account the learning in general, including work (Burke et al., 2005) 


\section{Google classroom}

Google Classroom is a Google-designed online learning platform that enables students and teachers to learn innovatively 'beyond class'(Islam, 2019). It is an online teaching and learning aid that enables assessments and appointments without paper. Also, both the teachers and students interact well so that they participate in teaching and learning outside the classroom. There is a timeline in Google Classroom that appears by default when someone enters the classroom. This stream can be used to gather student views by developing topics for discussion. As the platform relies on Google Drive to migrate archived and tasks, the e-portfolio approach is further encouraged. Students and teachers will create documents and directories that can be exchanged. If you work in groups, you can create a shared folder of your own. So even though one or more of the groups are missing, the function of the group is open to any group. All should be offbeat, considering that everything happens in the cloud.

Two academics and educators from early careers examined the efficiency of Google Classroom's use of primary school students in the final year to stimulate student voice and agency and examine how the platform can affect future tertiary pedagogies. Data shows that student engagement and learning in Google Classroom have increased and class dynamics have improved. It also showed doubts about the speed and experience of users. The data was used to develop a structure for evaluating the usage of on-line platforms; four principles (pace, easiness of access, etc were defined voice/agency students) who explore the utility of other pedagogical and online learning tools (Heggart \& Yoo, 2018). Google Classroom is one of Google's free Education Suite services. It encourages paperless preparation to develop tasks, promotes teamwork, and encourages seamless communication to increase the effectiveness and importance of teaching. Google Classroom can be deployed conveniently in the classroom.google.com URL, teachers can set up a classroom and develop material for their students in minutes. It is free even for schools and top-level protection is included free of charge for plan holders (Classroom, 2017). It also features a mobile application for fast access anywhere and to provide educators with immediate feedback and track the progress of students in terms of success.

\section{TOEFL preparation}

Listening, structure, writing, and reading comprehension are the three parts of the TOEFL test. The focus of this analysis was on the TOEFL Training Class students' experiences. These results would make a realistic, institutional and academic contribution (Sari, et al., 2021; Suhono, 2019). The preparation course of TOEFL is designed to help students enter TOEFL The ITP score of 450, one of the criteria of the institutional testing program (YP Fatahillah Jakarta STIE Indonesia website, 2017). Certain TOEFL training courses will help students to increase the TOEFL score. TOEFL Preparation class was met by the majority of students. Before taking TOEFL, the teacher helped them understand English in contrast with their experience. But the students propose a minimum time of 120 minutes for each meeting. The teacher can also have group work and homework tasks. The instructor should also arrive on time at the class (Masfufah, 2018).

View of the importance of TOEFL Training in a Canadian university by Chinese students. Three items were disclosed in the report. First, students, instruction, and teaching material were of quality. The second was the advantages of TOEFL and English growth in performance and reorientation. Thirdly, commitment, and progress in learning groups and motivational sources occurred (Ma and Cheng, 2015). 
Related to the previous study a thesis by Annita Muslimah (2018) Entitled "A Survey on the Use of Google Classroom in English Language Education Department of Islamic University of Indonesia" found that the questionnaire included 23 items adapted from Shaharanee et al (2016). Frequency and means were used to analyze the results, the average score is $X^{-}=3.82$. According to the findings, students find that Google Classroom to be useful and are pleased with it as an online learning platform.

Based on problems above, this research aims to analyze the impact of preparation based on the specified problems and to investigate the expectations of students regarding the use of TOEFL preparation online using Google classroom. It will allow educators to inspire students to develop their English skills by considering their perceptions. Since TOEFL preparation interpret via Google Classroom, do they believe it will be successful in TOEFL preparation through Google Classroom.

\section{METHOD}

A quantitative descriptive approach was the concept of this study. Descriptive analysis included data collection to address the test hypotheses or a question about the current status of the topic of the research (Gay et al.,2009). It concluded that the descriptive method would be to help research to collect the data. Instruments were used to collect data and information. The population of this research was the eighthsemester students of Sekolah Tinggi Ilmu Kesehatan Siti Khadijah Palembang, Nursing Study Program Palembang in Academic Year 2019/2020 consist of 62 students. The total sampling of this research was chosen to get a sample of this research. Total sampling is a sampling procedure in which the number of samples is equal to the number of people in the population. It means that the sample of this research was all the students included as the population of the research.

In this research, the writer used the questionnaire form (Shaharanee et al., 2016), and to build the questionnaire, it used references from the internet self-efficacy scale (Eastin et al., 2000). With a score above 0.90, the questionnaire is accurate and Google Classroom is also tested. The instrument of this research was a questionnaire that consists of 23 items. Each item consists of Simplicity connection consists of 6 questions, Usefulness of Perceivable consists of 7 questions, Interaction and Communication consist of 6 questions, and The satisfaction of Students consists of 4 questions. A Likert scale was used in the responses to each object. The several measuring about social phenomena by using a Likert scale as attitudes, opinions, and some perceptions (Sugiyono, 2013). There was a level ranging from very positive to very negative for any questionnaire object. Respondents using the following Likert scale answered the questions:

Table 1. The Statements on the Likert scale

\begin{tabular}{c|c}
\hline Likert Scale & Score \\
\hline Strongly agree & 5 \\
\hline Agree & 4 \\
\hline Neutral & 3 \\
\hline Disagree & 2 \\
\hline Strongly Disagree & 1 \\
\hline
\end{tabular}


Larger total of students, more satisfied Google Classroom students are pleased, it showed that as an engaging learning site, Google Classroom is useful and effective. To analyze the data, the researchers performed several procedures. There were 23 items were taken from the questionnaire used in this research. The first section to gather data from respondents such as gender and the frequency of internet access of the students. To get the information on the questionnaire, the writer used google form. The variables are rated from 1 (strongly disagree) to 5 (strongly agree).

The study results in the form of numbers and data interpretation using statistics, thi s study approach has the style of the quantitative method. The measures in this analysis to interpret the data is as follows:

1. Online learning, Google Classroom, and learning media reviewing.

2. To make sure that it is easy to grasp the context, search one by one thing in the questionnaire.

3. Distributing 23 questionnaire items via Google form to 62 students Nursing Study Program.

4. Then use a Microsoft Excel program to analyze questionnaire details into a statistical package.

5. By determining the total score from the highest to the lowest outcome, the key outcomes can be evaluated. A high score shows the respondents are satisfied with Google Classroom; thus, as an active learning platform, it illustrates that it is useful and effective. The low score implies that respondents are not comfortable with Google Classroom.

\section{RESULT AND DISCUSSION}

Personal details of the respondent who completed the questionnaire as shown in the table below:

Table 2. The result of respondent personal information

\begin{tabular}{c|c}
\hline Male & Female \\
\hline 14 & 48 \\
\hline
\end{tabular}

Table 3. The frequency of internet access

\begin{tabular}{c|c|c}
\hline Internet Access & Frequency & Percentage \\
\hline Never & 1 & $2 \%$ \\
\hline Once a week & 1 & $2 \%$ \\
\hline Several times a week & 7 & $10 \%$ \\
\hline Once a day & 11 & $18 \%$ \\
\hline Several times a day & 42 & $68 \%$ \\
\hline
\end{tabular}

The number of student who completed the questionnaire was 62, with females responsible for 48 of them and males responsible for 15 of them. $68 \%$ of those interviewed say they use the internet more than once a day. It means the majority of respondents are comfortable using the internet and web-based programs. 


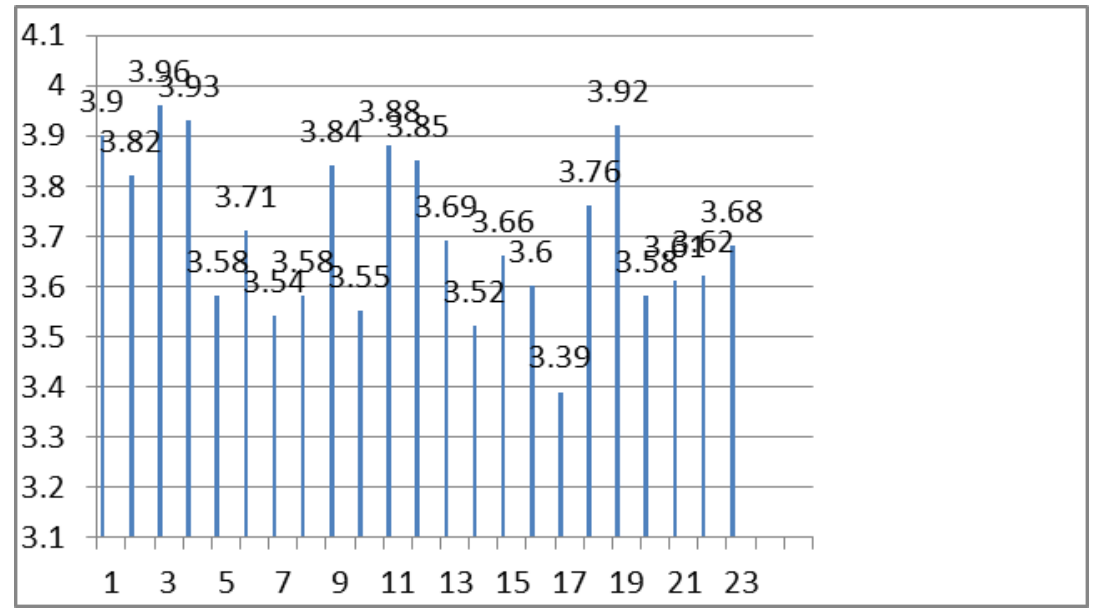

Figure 1. Responses from students on the use of Google Classroom

There were 23 questions about the answers of students use of Google Classroom. This research was done at Sekolah Tinggi Ilmu Kesehatan Siti Khadijah Palembang. The details reveal that 3.96 was the best score and 3.39 was the lowest score. Question Number 3 has the highest overall average of the findings (Sending and receiving assignment) with a score of 3.96 on the base of the whole questionnaire finding, Question number 17 earns the lowest score of the entire data collection. (My point of view was acknowledged by other participants during this activity) with the score 3.39 .

Each Part of the Questionnaire Simplicity of Connection

Based on the results of the respondents' answers to the questionnaire, the simplicity of the connection average is as shown in the chart below:

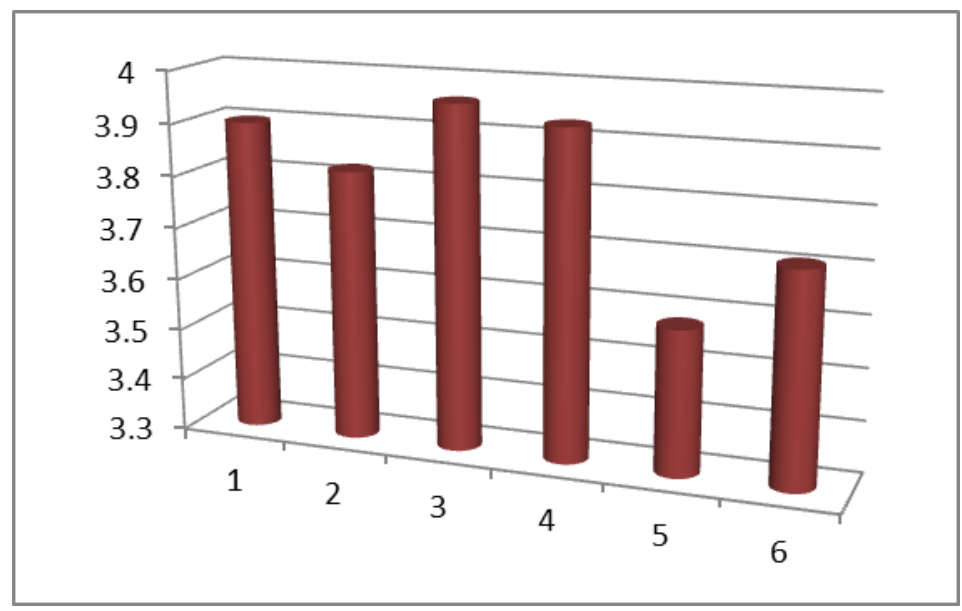

Figure 2. The Average Simplicity of Connection

The statements are seen in the questionnaire; (1) logging into the Google Classroom; (2) downloading resources from the course; (3) sending and receiving assignments; (4) posting assignments; (5) navigating the system; (6) recognizing the system quickly. The following map illustrates the ease of entry to Google Classroom. The highest average with a score of 3.96 is from issue number 3 (sending and receiving 
assignment). It can also be inferred that respondents believe that a task can be submitted and retrieved quickly by Google classroom.

Usefulness as perceivable

Based on the responses of the students to the questionnaire. The average of Usefulness as perceivable is as shown in the chart below:

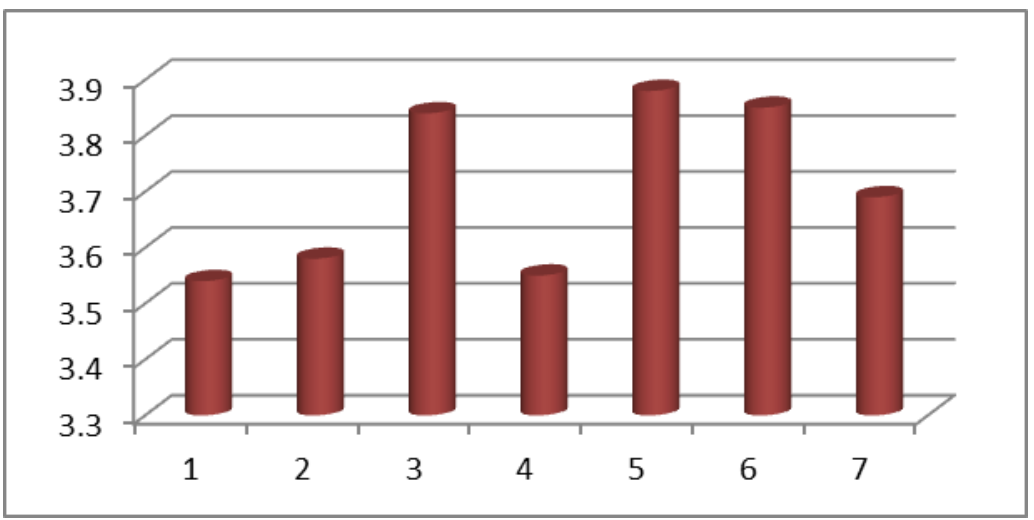

Figure 3. The average of perceived usefulness

The statements are seen in the questionnaire;(1) the content of the learning experience was excellent; (2) google classroom is an excellent tool for social networking (lecturer vs student and student vs student) as shown by this exercise; (3) google classroom helps me send assignments on time; (4) the course activities helped me to analyze questions, test new ideas, and adapt what I have learned; (5) the feedback provided by the course activities; (6) the Google classroom grading system aids in tracking my success and recognizing the current topic discussed; (7) the purpose, evaluation and substance of the subject is compatible with the aid of Google Classroom. The chart above describes the usefulness as perceivable of Google Classroom. Question number 5 has the highest average. (The feedback provided by the course activities) with a score of 3.88. It can be inferred that respondents believe Google Classroom has feedback provided by the lecturer.

Interaction and Communication

Based on the results of the students' questionnaire responses. The average interaction and communication are shown as in the chart below:

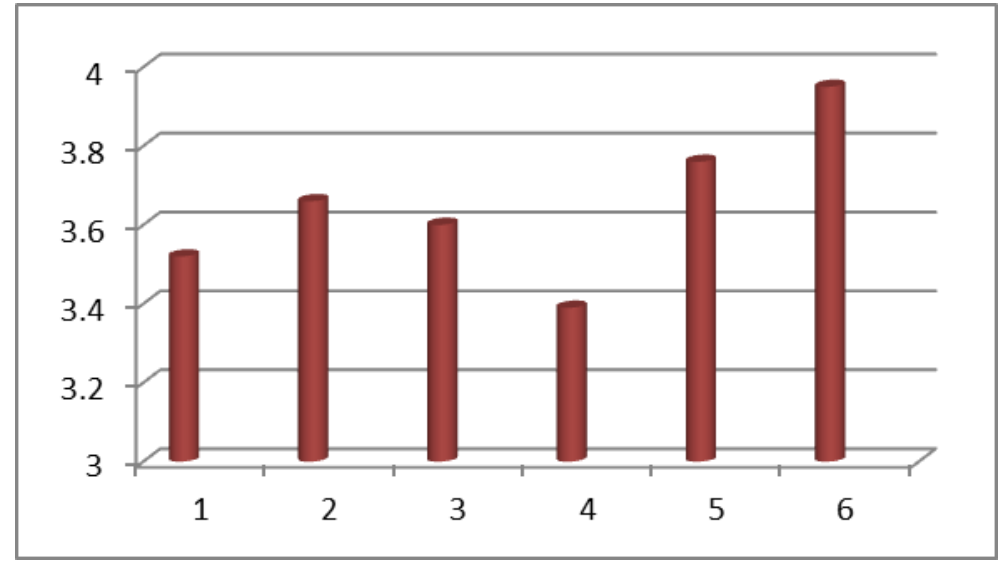

Figure 4 . The average of communication and interaction 
The statements are seen in the questionnaire,(1) For this activity, I felt relaxed talking through this medium;(2)the lecturer helped preserve participants in the course engaged and engaging in constructive discussion; (3)I felt comfortable communicating with other participants in this activity; (4) During this activity, my point of view was understood by other participants;(5)Lecturers are excited about teaching and demonstrating via the Google Classroom;(6) Lecturers are polite, open and can be reached easily.

The chart above illustrates how Google Classroom users interact and communicate. Question number 6 has the highest average (Lecturers are polite, open, and can be reached easily) with a score of 3,93. Therefore, it can be concluded that in Google classroom communication and interaction with the lecturer was pleasant, personable, and easily contactable.

\section{The Satisfaction of Students}

Based on the results of the questionnaire filled out by the students. The average student satisfaction as shown in the chart below:

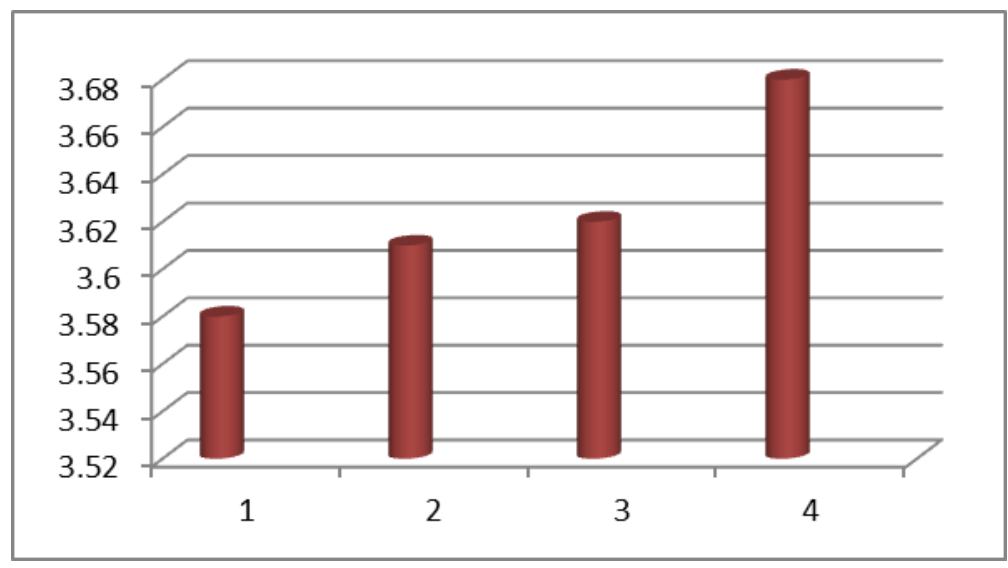

Figure 5. Satisfaction of students

The statements are seen in the questionnaire,(1) the subject fulfilled my personal goal;(2) I would suggest this form of learning to be extended to another suitable subject; (3) my first preference of active learning is Google classroom as opposed to another method; (4) as a source of motivation and learning initiative, I like the Google Classroom. The following chart describes the satisfaction of respondents with using Google Classroom. Question number 4 (I like the Google Classroom as a learning initiative and motivation booster) has the best average with a score of 3.68. It can be inferred that respondents sense the pleasure of Google Classroom as a learning tool and a motivation booster for students. This study used a questionnaire that was taken from another study (Sugiyono, 2013). The questionnaire is used to gather data on the reactions of students to the use of Google Classroom for Nursing Science students. The researcher further expanded on the data processing findings that were discussed earlier.

The results of the data, based on the chart, the highest average comes from question number 3 (sending and receiving assignment) with a score of 3.96. Question number 17 has the lowest score of the entire data collection (My point of view was acknowledged by other participants during this activity) with a score of 3.39. Each part of the questionnaire is defined in the second phase. The simplicity of the 
connection consists of 6 questions with an average $X^{-}=3.78$. The highest score is number 3 (sending and receiving assignment) with an average of 3.96, which means respondents believe that Google Classroom makes it easy for them to submit and receive an assignment. Number 5 is the lowest score (navigating the system) with an average of 3.58, which indicates respondents believe that the Google Classroom navigation system is simple. It is still included in the high category.

There are seven questions in the Perceived Usefulness section, with an average $X^{-}=3.64$. Number 5 is the highest score. (The lecturer's feedback is helpful) with an average of 3.88, suggesting that respondents believe that Google Classroom offers useful lecture feedback. With a score of 3.54, the lowest score is 1 (the level of learning activity was excellent), suggesting that respondents believe that Google Classroom would not increase the quality of learning activity. Despite this, it is still listed as a large product. Communication and Interaction is made up of 6 questions, the sum of which is $X^{-}=3.6$. The number one score (Lecturers are friendly, personable, and easily contacted) has an average of 3.95, showing that students believe that Google Classroom encourages communication and interaction. With an average of 3.39, number 4 (During this activity, other participants recognized my point of view) gets the lowest score, suggesting that respondents are neutral regarding My point of view being recognized by other participants. The Student Satisfaction Questionnaire consists of four questions with an average $X^{-}=3.57$. With an average of 3.68, number 4 (I like Google Classroom as a learning initiative and motivation booster) earns the highest score, suggesting that respondents agree that Google Classroom is a successful learning initiative and motivation booster. With an average of 3.58, the lowest score is 1 (Via the medium introduced, the topic reached my personal target), suggesting that respondents believe that Google Classroom would not help them achieve their personal goal. Nonetheless, it falls into the high category. From analysis above, the highest score comes from question number 3 (sending and receiving assignment) with score 3.96 and the lowest score comes from question number 17 ( my point of view was acknowledged by other participants during this activity) with score 3.39. From every part of questionnaire found that the first part of question was the simplicity of the connection with average $X$ ${ }^{-}=3.78$, the second part of question was perceived usefulness with average $X^{-}=3.64$, the third part of question was communication and interaction with average $X^{-}=3.6$, and the last part of question was student satisfaction with average $X^{-}=3.57$.

This finding supported by Hapsari \& Pamungkas (2019), showed that communication learning with media, for instance Google Classrom was able to increase student motivation and computer skills. Other finding, Abd. Rozak and Azkia Muharom Albantani (2018), entitled the design oflectures Arabic through Google Classroom, shows that this application can help facilitate lecturers and students in carrying out theprocess learningmore deeply. This is because both students and lecturers can collect assignments, distribute assignments, and assess assignments at home or anywhere without being bound by time limits or class hours. While a research by Pritasari \& Jumadi (2018) shows that the implementation of tools -based learning problem with the google classroom provides a new alternative in improving the quality of science education achievement. The advantage of google class room media was effectiveness and efficiency in learning. Google classroom makes teaching and learning activities more productive and meaningful by simplifying assignments, increasing collaboration, and fostering communication (Wicaksono, 2020). Teachers can create classes, assign assignments, send feedback, and see everything in one place. 
Other findings also agree that Google Classroom is the technology most important communicationin the process learning. The greatness of communication technology is marked by the presence of the method, which e-learning Google Classroom is a means of facilitating long-distance communication between teachers and students, especially in theclass Digital Content Management (Wahyuni, et al., 2021; Sukmawati \& Nensia, 2019; Syakur, et al., 2021). A means of learning together, receiving and reading materials, sending assignments remotely to presenting the value of assignments in a transparent manner. All students involved in this learning process get the same opportunities. Teachers in the use of Google classroom in cooperative learning strategies are still encountered several students who are less active in the implementation of learning (Sholikh, et al., 2019), limited media projectors to display the work of students, and aninternet network inadequate. The advantages of Google classroom, as expressed by the social studies teacher at the research location, is to give homework to students, then the task is discussed with group members outside of school, andschool during it will be discussed with the teacher and all students in the class. Thus students continue to be active during the group work process so that students will be able to master the social studies material that has been implemented. Use of Google classroom also in value can cultivate the spirit and interests of students.

\section{CONCLUSION}

The conclusion of this research is focused on the analysis of studies and discussion on the responses of students to the use of Google Classroom. This analysis indicates that students in the Nursing Science Study Program usually find that accessing Google Classroom is easy $\left(X^{-}=3.78\right)$, Google Classroom perceives utility $\left(X^{-}\right.$ $=3.64$ ), Google Classroom makes it easy and comfortable for them to interact and communicate $\left(X^{-}=3.6\right)$, and Google Classroom satisfies students $\left(X^{-}=3.57\right)$. The outcome of this study indicates that for the students, Google Classroom is useful and helpful and they feel pleased with Google Classroom in TOEFL preparation. It is recommended that English lecturers pay more attention to helping students quickly access the Google Classroom method, use Google Classroom for social networking, be more passionate about teaching and explaining using Google Classroom, and provide students with feedback.

\section{ACKNOWLEDGMENTS}

The author would like thank to Allah SWT who has given much mercy and blessing, and all those who have helped in completing this researcher, grateful to Sekolah Tinggi Ilmu Kesehtan Siti Khadijah that supports the researchers. The acknowledgments are also given to Syamsul Rizal and Abdul Aziz Rifa' at who have participated in the process of implementing this research.

\section{AUTHOR CONTRIBUTION STATEMENTS}

Conceptualization, N.Y.A.; methodology, S.R.; software, N.Y.A and A.A.R.; validation, S.R.; formal analysis, N.Y.A.; investigation, A.A.R. ;resources, N.Y.A and S.Y.; data curation, S.R. and A.A.R.; writing-original draft preparation, N.Y.A.; writing-review and editing, N.Y.A. AND S.R..; visualization, A.A.R..; supervision, S.R..; project administration, A.A.R. 


\section{REFERENCES}

Al Rawashdeh,H.(2011).Difficulties that face graduate students during their TOEFL preparation program at Jordanian universities.A bath Al-Yarmouk "Hum.ESoc. Sci",2307-2329. Google Scholar

Becker, A. (2016). L2 students' performance on listening comprehension items targeting local and global information. Journal of English for Academic Purposes, 24, 1-13. https:// doi.org/10.1016/j.jeap.2016.07.004

Burke V,Jones I and Doherty M (2005).Analysing student perceptions of transferable skills via undergraduate degree programmes. Active Learning in Higher Education 6(2): 132-44.

Classroom | Google for Education.(n.d.).Retrieved November 29,2017, Google Scholar

Eastin,M.S.,\&LaRose,R.(2000).Internet self-efficacy and the psychology of the digital divide. Journal of Computer-Mediated Communication, v6 n1 Sep 2000.

Gay,L.R.,and P .Airisian.(2009).Educational Research:Competencies for Analysis and Application (Ninth Edition).New York:Prentice-Hall.

Gupta, A., \& Pathania, P. (2021). To study the impact of Google Classroom as a platform of learning and collaboration at the teacher education level. Education and Information Technologies, 26(1), 843-857. https://doi.org/10.1007/s10639-02010294-1

Hapsari, S. A., \& Pamungkas, H. (2019). Pemanfaatan google classroom sebagai media pembelajaran online di universitas dian nuswantoro. WACANA: Jurnal Ilmiah Ilmu Komunikasi, 18(2), 225-233. https:/ / doi.org/10.32509/ wacana.v18i2.924

Hemrungrote, S., Jakkaew, P., \& Assawaboonmee, S. (2017, March). Deployment of Google Classroom to enhance SDL cognitive skills: A case study of introduction to information technology course. In 2017 International Conference on Digital Arts, Media and Technology (ICDAMT) (pp. 200-204). IEEE. https:// doi.org/10.1109/ICDAMT.2017.7904961

Heggart,K.R.,\&Yoo,J.(2018).Getting the most from google classroom:A pedagogical framework for tertiary educators.Australian Journal of Teacher Education,43(3), 140153. https:// doi.org/10.14221/ajte.2018v43n3.9.

Hwang, et al., (2015).Seamless flipped learning:a mobile technology-enhanced flipped classroom with effective learning strategies. Journal of Computers in Education, 2(4), 449-473. https:// doi.org/10.1007/s40692-015-0043-0.

Inoue, C., \& Lam, D. M. (2021). The Effects of Extended Planning Time on Candidates' Performance, Processes, and Strategy Use in the Lecture Listening-Into-Speaking Tasks of the TOEFL iBT® Test. ETS Research Report Series. https:// doi.org/10.1002/ets2.12322

Islam,S.(2019).Bangladeshi University Students' Perception on Using Google Classroom for Teaching English. International Journal of Psycho-Educational Sciences |,8(2), 58.

Kabilan,M.K.,Ahmad,N.,\&Abidin,M.J.Z.(2010).Facebook:An online environment for learning English in institutions of higher education?The Internet and Higher Education, 13(4),179-187.

Keller,C.,\&Cernerud,L.(2002).Students' Perceptions of E-learning in University Education. Journal of Educational Media,27(1-2),55-67. https:// doi.org/10.1080/1358165020270105.

Masfufah,S.(2018).Indonesian College Students' Perceptions Of Toefl Preparation C. Journal of English Education, Literature, and Culture, 3(1),66-77. Google Scholar

Ma, J.,\&Cheng,L.(2015).Chinese students' perceptions of the value of test preparation 
courses for the TOEFL iBT: Merit, worth, and signifiance.TESL Canada Journal/ Revue TESL Du Canada, 33(1),58-79. Google Scholar

Muslimah,Anita, (2018). A Survey on the Use of Google Classroom in English Language Education Department of Islamic University Of Indonesia. A Thesis from Department of English Language Education Faculty of Psychology and Socio-Cultural Sciences Islamic University of Indonesia Yogyakarta, Indonesia.

Ockey, G. J., Koyama, D., Setoguchi, E., \& Sun, A. (2015). The extent to which TOEFL iBT speaking scores are associated with performance on oral language tasks and oral ability components for Japanese university students. Language Testing, 32(1), 39-62. https:/ / doi.org/10.1177\%2F0265532214538014

Pritasari, A. C., \& Jumadi, J. (2018). Development of science learning tool based on problem based learning with Google Classroom to improve argumentation skill. Biosaintifika: Journal of Biology \& Biology Education, 10(2), 348-355. https:// doi.org/10.15294/biosaintifika.v10i2.14320

Rozak, A., \& Albantani, A. M. (2018). Desain perkuliahan bahasa arab melalui google classroom. Arabiyat: Jurnal Pendidikan Bahasa Arab dan Kebahasaaraban, 5(1), 83-102. https:// doi.org/10.15408/a.v5i1.7481

Sari, Y. A., Latief, S., \& Umar Al Faruq, A. H. (2021). Student Difficulties on Structure and Written Expression Section of TOEFL In Higher Education at Metro City. Curricula: Journal of Teaching and Learning, 6(1), 33-69. Google Scholar

Shaharanee,I.N.M.,Jamil,J.M.,\&Rodzi,S.S.M.(2016). Google classroom as a tool for $\begin{array}{llll}\text { active learning.AIP } & \text { Conference } & \text { Proceedings, } & 1761 .\end{array}$ https:// doi.org/10.1063/1.4960909.

Sholikh, M. N., Sulisworo, D., \& Maruto, G. (2019). Effects of Cooperative blended learning using Google Classroom on critical thinking skills. Advances in Social Science, Education and Humanities Research, 349. Google Scholar

Sugiyono.(2013).Metode Penelitian Pendidikan Pendekatan Kuantitaif, Kualitatif, dan R\&DSugiyono. 2013.“Metode Penelitian Pendidikan Pendekatan Kuantitaif, Kualitatif, dan R\&D."Metode Penelitian Pendidikan Pendekatan Kuantitaif, Kualitatif, dan R\&D. https://doi.org/10.1.In Metode Penelitian Pendidikan Pendekatan Kuantitaif, Kualitatif, dan RED.

Suhono, S. (2019). Providing explicit strategy instruction to enhance students'reading comprehension at english for islamic studies class. Jurnal smart, 5(2), 81-93.Google Scholar

Suhono, S., Zuniati, M., Pratiwi, W., \& Hasyim, U. A. A. (2020). Clarifying Google Translate Problems Of Indonesia-English Translation Of Abstract Scientific Writing. Google Scholar

Sukmawati, S., \& Nensia, N. (2019). The Role of Google Classroom in ELT. International Journal for Educational and Vocational Studies, 1(2), 142-145. https:// doi.org/10.29103/ijevs.v1i2.1526

Syakur, A. (2020). The Effectiveness of English Learning Media through Google Classroom in Higher Education. Britain International of Linguistics Arts and Education (BIoLAE) Journal, 2(1), 475-483. https:// doi.org/10.33258/ biolae.v2i1.218

Wahyuni, V. S., Wulandari, D., \& Hardhienata, S. (2021). Long Distance Learning, Challenges And Opportunities. EDUTEC: Journal of Education And Technology, 4(3), 368-374. https://doi.org/10.33258/biolae.v2i1.218

Wawan, W., Marsigit, M., Ningsih, E. F., Widyawati, S., Kusumaningtyas, W., Mahmudi, M., ... \& Setiawan, A. (2018). Technology-Integrated Collaborative Learning: Convenient Al-ternative in Developing the Problem Solving Capability 
and Positive Attitude. International Journal of Engineering $\mathcal{E}$ Technology, 7(3.2), 737740. Google Scholar

Wicaksono, M. D. (2020). Pemanfaatan Google Classroom dalam Strategi Pembelajaran Kooperatif pada Mata Pelajaran Ips Kelas Viii. INSPIRASI: JURNAL ILMU-ILMU SOSIAL, 17(1). https:// doi.org/10.29100/insp.v17i1.1568.g714

Yayasan Pendidikan Fatahillah Jakarta Sekolah Tinggi Ilmu Ekonomi Indonesia,(2017, April 30).Program Studi S-1 Manajemen Sekolah Tinggi Ilmu Ekonomi Indonesia (STEI). Google Scholar

\section{Copyright Holder :}

(C) Suryani, N., Rizal, S., \& Rifa'at, A., (2021).

First Publication Right :

(c) Attractive : Innovative Education Journal

This article is under:

(ㅇ)(1) (2) 